\title{
Orthopaedic Surgeons' Knowledge and Misconceptions in the Identification of Intimate Partner Violence Against Women
}

\author{
Gregory J. Della Rocca MD, PhD, FACS, \\ Sheila Sprague MSc, Sonia Dosanjh MSW, \\ Emil H. Schemitsch MD, FRCS(C), Mohit Bhandari MD, PhD, FRCS(C)
}

Received: 24 July 2012/ Accepted: 5 December 2012/Published online: 3 January 2013

(C) The Association of Bone and Joint Surgeons $\mathbb{R} 2012$

\begin{abstract}
Background Intimate partner violence (IPV)—physical, sexual, psychologic, or financial abuse between intimate partners-is the most common cause of nonfatal injury to women in North America. As many IPV-related injuries are musculoskeletal, orthopaedic surgeons are well positioned to identify and assist these patients. However, data are lacking regarding surgeons' knowledge of the prevalence of IPV in orthopaedic practices, surgeons' screening and management methods, and surgeons' perceptions about IPV.

Questions/purposes We aimed to identify (1) surgeon attitudes and beliefs regarding victims of IPV and batterers

All ICMJE Conflict of Interest Forms for authors and Clinical Orthopaedics and Related Research editors and board members are on file with the publication and can be viewed on request.

Each author certifies that his or her institution approved the human protocol for this investigation, that all investigations were conducted in conformity with ethical principles of research, and that informed consent for participation in the study was obtained.

This work was performed at Division of Orthopaedic Surgery, Department of Surgery and the Department of Clinical Epidemiology and Biostatistics, McMaster University, Hamilton, Ontario.
\end{abstract}

G. J. Della Rocca $(\bowtie)$

Department of Orthopaedic Surgery, University

of Missouri, 1 Hospital Drive, N116, DC053.10,

Columbia, Missouri 65212, USA

e-mail: dellaroccag@health.missouri.edu

S. Sprague, S. Dosanjh, M. Bhandari

Division of Orthopaedic Surgery, Department of Surgery and the Department of Clinical Epidemiology and Biostatistics, McMaster University, Hamilton, Ontario, Canada

E. H. Schemitsch

Division of Orthopaedics, Department of Surgery, University

of Toronto, St. Michael's Hospital, Toronto, Ontario, Canada and (2) perceptions of surgeons regarding their role in identifying and assisting victims of IPV.

Methods We surveyed 690 surgeon members of the Orthopaedic Trauma Association. The survey had three sections: (1) general perception of orthopaedic surgeons regarding IPV; (2) perceptions of orthopaedic surgeons regarding victims and batterers; and (3) orthopaedic relevance of IPV. One hundred fifty-three surgeons responded (22\%).

Results Respondents manifested key misconceptions: (1) victims must be getting something out of the abusive relationships (16\%); (2) some women have personalities that cause the abuse (20\%); and (3) the battering would stop if the batterer quit abusing alcohol (40\%). In the past year, approximately $1 / 2$ the respondents (51\%) acknowledged identifying a victim of IPV; however, only $4 \%$ of respondents currently screen injured female patients for IPV. Surgeons expressed concerns regarding lack of knowledge in the management of abused women (30\%).

Conclusion Orthopaedic surgeons had several misconceptions about victims of IPV and batterers. Targeted educational programs on IPV are needed for surgeons routinely caring for injured women.

\section{Introduction}

Injuries are among the leading causes of death for females aged 1 to 34 years and represent major sources of morbidity and mortality for middle-aged and elderly women [9, 14]. According to the Federal Bureau of Investigation, more than $1 / 2$ of murdered women were killed by a person with whom they were acquainted, and approximately $30 \%$ of women were killed by a current or former intimate partner [27]. In North America, domestic violence is also 
the most common cause of nonfatal injury to women $[9,14]$. Greater than $40 \%$ of women have experienced one or more forms of violence: child abuse $(17.8 \%)$, physical assault $(19.1 \%)$, rape $(20.4 \%)$, and/or intimate partner violence (IPV) $(34.6 \%)$ [20].

Intimate partner violence, also known as domestic violence, spousal violence, and battery has been receiving increased attention as a serious public health problem. Intimate partner violence represents a pattern of assaultive and coercive behaviors, which can include one or more of the following: physical, sexual, and psychologic attacks, and economic coercion. Victims of IPV are known to use health services at higher rates than women who have not been abused [12, 18, 20, 21]; therefore, healthcare providers are in good positions to identify and assist victims of IPV.

Musculoskeletal injuries are commonly seen in victims of IPV. The most prevalent of these are head and neck injuries (40\%) followed by other musculoskeletal injuries (28\%) [3], and one report on 144 victims of IPV detailed the types of musculoskeletal injuries seen, which included sprains (15\%), fractures or dislocations (12\%), and foot injuries (1\%) [3]. Orthopaedic surgeons, as providers of musculoskeletal care, can be first-contact healthcare practitioners for many patients. They establish ongoing relationships with these patients and have the opportunity to help victims of IPV. The importance of identifying IPV has been recognized by national orthopaedic organizations. The American Academy of Orthopaedic Surgeons (AAOS) guidelines suggest that orthopaedic surgeons appropriately screen for problems of domestic violence and document them in the medical record, assess and assure the safety of the victim, appropriately treat victims, and take steps to prevent further harm [1]. The Canadian Orthopaedic Association (COA) notes that orthopaedic surgeons are well-positioned to identify patients living with IPV and initiate intervention, encourages members to educate themselves further about IPV, and states that it is good medical practice to take steps to identify and offer assistance to IPV victims [7].

We conducted an observational study to identify (1) surgeon attitudes and beliefs regarding batterers and victims of IPV and (2) surgeon perceptions regarding the identification and role in assisting victims of IPV in their orthopaedic practices.

\section{Materials and Methods}

All 690 active members of the Orthopaedic Trauma Association (OTA) were asked to participate in the survey. We chose OTA members, as their clinics have high proportions of acutely injured patients. Requests for participation were sent via three mass electronic mail communications from the OTA headquarters. Participants chose to take part in the survey independently, and therefore, passive consent was implied. The survey was limited to members of the OTA by allowing access to the survey site only through the members-only logon at the OTA website (approved by the OTA Research Committee). Of 690 members, 153 surgeons responded to the survey $(22 \%$ response rate). Respondents were 90\% male (137/153), and 96\% (147/153) of them practiced in North America. All but four respondents were 30 to 60 years old. Our response rate (153/690) yielded a 95\% CI in the accuracy of the survey, with a $7 \%$ margin of error.

The survey was administered from a website independent of the OTA's website (SurveyMonkey ${ }^{\circledR}$, www. surveymonkey.com, Palo Alto, CA) and therefore the respondents' identities could not be discerned. No incentives were provided to the study participants. All data were password protected and only OTA staff members and the current authors had access to the data. Participants were able to choose to abstain from answering some or all of the study questions without obviating their ability to complete the survey and submit the results of the questions that were answered. All survey results were pooled to minimize the likelihood of identifying individual participants by their demographics. The results were presented in tables. "Preferred responses" were indicated based on past studies that identified attitudes and beliefs of domestic violence among providers as barriers against effective clinical response $[5,6,10,11,15,22,25]$. The survey was administered over approximately 4 months during the summer of 2009 .

The survey questionnaire was minimally modified from the original provider survey, developed by the Violence Against Women Health Research Collaborative [5] and is divided into three sections. After a section that asks basic questions regarding the age and sex of the practitioner and the scope of his or her practice, surgeons were asked about their general attitudes toward IPV, their attitudes toward victims of IPV and batterers, and their beliefs regarding the relevance of IPV in orthopaedic practice. The surgeons' knowledge was assessed by a series of nine questions regarding exposure to victims of IPV in their clinics, their perceived ability to manage this problem, and their interest in attending training regarding identification and management of victims of IPV. The next section of the survey was comprised of 39 individual items and has been validated [5, 15]. This part of the survey was divided into three subsections. The first subsection was designed to identify perceptions of surgeons regarding identification and treatment of victims of IPV in orthopaedic clinics. The second subsection asked questions regarding the attitudes and beliefs of the surgeons regarding batterers and victims of IPV (Table 1), perceived factors that increase or decrease the likelihood of violence (Table 2), and attitudes toward the surgeon's role in addressing IPV (Table 3). The third 
Table 1. Responses regarding attitudes towards batterers and victims

\begin{tabular}{lll}
\hline $\begin{array}{l}\text { Issue (total number } \\
\text { of respondents) }\end{array}$ & $\begin{array}{l}\text { Number of } \\
\text { respondents }\end{array}$ & $\%$ \\
\hline
\end{tabular}

Treatment programs for batterers are not effective $(n=104)$

$\begin{array}{lll}\text { Agree } & 24 & 23 \% \\ \text { Neutral } & 50 & 48 \% \\ \text { Disagree } & 30 & 29 \%\end{array}$

Victim must be getting something out of relationship $(\mathrm{n}=129)$

$\begin{array}{lll}\text { Agree } & 20 & 16 \% \\ \text { Neutral } & 24 & 19 \% \\ \text { Disagree } & 85 & 66 \%\end{array}$

Not my place to interfere with couples' conflict resolution $(\mathrm{n}=130)$

$\begin{array}{ll}\text { Agree } & 10 \\ \text { Neutral } & 28 \\ \text { Disagree } & 92\end{array}$

I don't have time to ask about IPV $(\mathrm{n}=130)$

$\begin{array}{lll}\text { Agree } & 18 & 14 \% \\ \text { Neutral } & 30 & 23 \% \\ \text { Disagree } & 82 & 63 \%\end{array}$

I am afraid of offending patient if I ask about IPV $(n=129)$

$\begin{array}{lc}\text { Agree } & 27 \\ \text { Neutral } & 20 \\ \text { Disagree } & 82 \\ \text { Asking about IPV is an invasion of privacy } \\ \text { Agree } & 7 \\ \text { Neutral } & 14 \\ \text { Disagree* } & 107\end{array}$

Investigating cause of injury is not part of medical care $(\mathrm{n}=128)$

$\begin{array}{lr}\text { Agree } & 2 \\ \text { Neutral } & 7 \\ \text { Disagree* }^{*} & 119\end{array}$

Patients who do not reveal abuse feel it is not my business $(\mathrm{n}=128)$

$\begin{array}{ll}\text { Agree } & 12 \\ \text { Neutral } & 27 \\ \text { Disagree* } & 89\end{array}$

It is demeaning to question patients about abuse $(n=129)$

$\begin{array}{lr}\text { Agree } & 10 \\ \text { Neutral } & 19 \\ \text { Disagree* }^{*} & 100\end{array}$

Nonabused patients will get angry if asked about IPV $(\mathrm{n}=128)$

$\begin{array}{ll}\text { Agree } & 25 \\ \text { Neutral } & 29 \\ \text { Disagree* } & 74\end{array}$

People are victims because they choose to be $(n=129)$

\begin{tabular}{lrr} 
Agree & 7 & $5 \%$ \\
Neutral & 13 & $10 \%$ \\
Disagree* $^{*}$ & 109 & $84 \%$ \\
\hline
\end{tabular}

$64 \%$
Table 1. continued

Issue (total number

of respondents)

$$
\begin{aligned}
& \text { Number of } \\
& \text { respondents }
\end{aligned}
$$

It takes two to tango - both victim and batterer are responsible $(\mathrm{n}=129)$

$\begin{array}{lrr}\text { Agree } & 9 & 7 \% \\ \text { Neutral } & 14 & 11 \% \\ \text { Disagree* } & 106 & 82 \%\end{array}$

Victim has done something to bring about violence $(n=128)$

$\begin{array}{lrr}\text { Agree } & 6 & 5 \% \\ \text { Neutral } & 18 & 14 \% \\ \text { Disagree* } & 104 & 81 \%\end{array}$

I am reluctant to ask batterers about abusive behavior due to personal safety concerns $(n=126)$

Agree 33

Neutral $34 \quad 27 \%$

Disagree $\quad 59 \quad 47 \%$

Insufficent security at my workplace to permit IPV discussion with batterers $(\mathrm{n}=112)$

$\begin{array}{lll}\text { Agree } & 29 & 26 \% \\ \text { Neutral } & 29 & 26 \% \\ \text { Disagree } & 54 & 48 \%\end{array}$

Afraid of offending patients if I ask about their abusive behavior $(\mathrm{n}=126)$

Agree $\quad 50 \quad 40 \%$

Neutral $26 \quad 21 \%$

Disagree* $50 \quad 40 \%$

No way to ask batterers about IPV without putting victim in danger $(n=126)$

Agree $\quad 23 \quad 18 \%$

Neutral $44 \quad 35 \%$

Disagree $59 \quad 47 \%$

If I talk to batterer, I will increase risk for victim $(n=126)$

$\begin{array}{lll}\text { Agree* } & 49 & 39 \% \\ \text { Neutral } & 42 & 33 \% \\ \text { Disagree } & 35 & 28 \%\end{array}$

I can effectively discuss issues of abuse with a battering patient $(\mathrm{n}=125)$

\begin{tabular}{lll} 
Agree & 24 & $19 \%$ \\
Neutral & 45 & $36 \%$ \\
Disagree & 56 & $45 \%$ \\
\hline
\end{tabular}

* Preferred responses where applicable [4, 15, 17-21]; IPV = intimate partner violence.

subsection asked questions regarding presentations of patients to orthopaedic trauma clinics that might lead to suspicions on the part of the abusers, and the necessity of written guidelines for detection and treatment of patients with IPV in orthopaedic clinics. The survey previously had been administered to the COA [5] and chiropractors in the United States [26]. Descriptive modifications were made to the original provider survey [15] such that the analysis 
would be applicable to the orthopaedic field, and it was identical to the COA survey [5].

\section{Results}

Surgeons had several key misconceptions regarding IPV: victims get something out of the abusive relationships (16\%) (Table 1), some women have personalities that cause the abuse (20\%), and the battering would stop if the batterer quit abusing alcohol (40\%) (Table 2). Most respondents (71\%) disagreed that they could do little to help the patients since victims of IPV are unlikely to leave the abusive relationships, and 5\% indicated that victims of IPV choose to be victims. Regarding victims' culpability in their own abuse, 5\% of respondents indicated that the victims do something that directly brings about violence, and $7 \%$ answered that the victims and the batterers are responsible for the abuse (ie, "it takes two to tango") (Table 1). Only one set of responses varied based on respondent age. Respondents aged 51 to 60

Table 2. Responses regarding perceived factors that influence IPV

\begin{tabular}{lll}
\hline $\begin{array}{l}\text { Issue (total number } \\
\text { of respondents) }\end{array}$ & $\begin{array}{l}\text { Number of } \\
\text { respondents }\end{array}$ & $\%$ \\
\hline
\end{tabular}

IPV gets more frequent and severe over time $(\mathrm{n}=131)$

$\begin{array}{lrr}\text { Agree } & 111 & 85 \% \\ \text { Neutral } & 18 & 14 \% \\ \text { Disagree } & 2 & 2 \%\end{array}$

I have patients whose personalities cause them to be abused $(\mathrm{n}=129)$

$\begin{array}{lll}\text { Agree } & 26 & 20 \% \\ \text { Neutral } & 29 & 22 \% \\ \text { Disagree* }^{*} & 74 & 57 \%\end{array}$

Women in nontraditional roles cause IPV $(\mathrm{n}=128)$

$\begin{array}{lrr}\text { Agree } & 3 & 2 \% \\ \text { Neutral } & 13 & 10 \% \\ \text { Disagree* } & 112 & 88 \%\end{array}$

The victim's passive-dependent personality leads to abuse $(n=128)$

$\begin{array}{lll}\text { Agree } & 29 & 23 \% \\ \text { Neutral } & 35 & 27 \% \\ \text { Disagree* } & 64 & 50 \%\end{array}$

Batterers direct anger towards providers when challenged $(n=126)$

$\begin{array}{lll}\text { Agree } & 31 & 25 \% \\ \text { Neutral } & 58 & 46 \% \\ \text { Disagree* } & 37 & 29 \%\end{array}$

Battering will stop if batterer quits abusing alcohol $(n=126)$

\begin{tabular}{lll} 
Agree & 54 & $43 \%$ \\
Neutral & 38 & $30 \%$ \\
Disagree* & 34 & $27 \%$ \\
\hline
\end{tabular}

* Preferred responses where applicable [4, 15, 17-21]; IPV = intimate partner violence.

Table 3. Responses regarding perceived surgeon roles in addressing IPV among their patients

\begin{tabular}{lll}
\hline $\begin{array}{l}\text { Issue (total number } \\
\text { of respondents) }\end{array}$ & $\begin{array}{l}\text { Number of } \\
\text { respondents }\end{array}$ & $\%$ \\
\hline
\end{tabular}

There are ways to ask about abusive behavior without putting myself at risk $(n=124)$

$\begin{array}{lll}\text { Agree } & 75 & 60 \% \\ \text { Neutral } & 37 & 30 \% \\ \text { Disagree } & 12 & 10 \%\end{array}$

Strategies exist that I can use to encourage batterers to get help $(\mathrm{n}=125)$

$\begin{array}{lll}\text { Agree } & 57 & 46 \% \\ \text { Neutral } & 48 & 38 \% \\ \text { Disagree } & 20 & 16 \%\end{array}$

There are ways I can ask batterers about behavior that will minimize victim risk $(\mathrm{n}=126)$

$\begin{array}{lll}\text { Agree } & 52 & 41 \% \\ \text { Neutral } & 57 & 45 \% \\ \text { Disagree } & 17 & 13 \%\end{array}$

Role of the healthcare provider is limited in helping IPV victims $(\mathrm{n}=131)$

$\begin{array}{lll}\text { Agree } & 31 & 24 \%\end{array}$

$\begin{array}{lll}\text { Neutral } & 22 & 17 \%\end{array}$

$\begin{array}{lll}\text { Disagree } & 78 & 60 \%\end{array}$

I don't know what to do if I find an IPV victim $(n=129)$

Agree $\quad 42 \quad 33 \%$

$\begin{array}{lll}\text { Neutral } & 22 & 17 \%\end{array}$

Disagree $\quad 65 \quad 50 \%$

Nothing I can do because victim is unlikely to leave relationship $(\mathrm{n}=129)$

Agree $\quad 7 \quad 5 \%$

$\begin{array}{lll}\text { Neutral } & 30 & 23 \%\end{array}$

$\begin{array}{lll}\text { Disagree } & 92 & 71 \%\end{array}$

I don't know how to ask about the possibility of IPV $(\mathrm{n}=129)$

$\begin{array}{lll}\text { Agree } & 37 & 29 \%\end{array}$

Neutral $21 \quad 16 \%$

Disagree $\quad 71 \quad 55 \%$

Identifying IPV victims is relevant to my practice $(n=145)$

Not at all relevant $\quad 1 \%$

Possibly relevant $\quad 36 \quad 25 \%$

Somewhat relevant $\quad 54 \quad 37 \%$

$\begin{array}{lll}\text { Very relevant } & 54 & 37 \%\end{array}$

Assessing female patients for IPV is a low-priority issue $(\mathrm{n}=146)$

Agree $\quad 32 \quad 22 \%$

Neutral $\quad 40 \quad 28 \%$

Disagree $\quad 73 \quad 50 \%$

Reporting of IPV is mandatory in my jurisdiction $(n=145)$

Yes $\quad 49 \quad 34 \%$

No $19 \quad 13 \%$

$\begin{array}{lll}\text { Unsure } & 77 & 53 \%\end{array}$ 
Table 3. continued

\begin{tabular}{|c|c|c|}
\hline $\begin{array}{l}\text { Issue (total number } \\
\text { of respondents) }\end{array}$ & $\begin{array}{l}\text { Number of } \\
\text { respondents }\end{array}$ & $\%$ \\
\hline \multicolumn{3}{|c|}{$\begin{array}{l}\text { I have attended an educational/training session on IPV } \\
\quad(n=146)\end{array}$} \\
\hline Yes & 33 & $22 \%$ \\
\hline No & 109 & $75 \%$ \\
\hline Unsure & 4 & $3 \%$ \\
\hline \multicolumn{3}{|c|}{$\begin{array}{l}\text { My clinic has written guidelines for detection or management } \\
\text { of IPV }(n=129)\end{array}$} \\
\hline Yes & 10 & $8 \%$ \\
\hline No & 82 & $63 \%$ \\
\hline Unsure & 37 & $29 \%$ \\
\hline \multicolumn{3}{|c|}{$\begin{array}{l}\text { Providing more IPV information to ortho surgeons could be } \\
\text { beneficial to stopping abuse in some cases }(n=145)\end{array}$} \\
\hline Agree & 104 & $72 \%$ \\
\hline Unsure & 27 & $19 \%$ \\
\hline Disagree & 14 & $9 \%$ \\
\hline \multicolumn{3}{|c|}{$\begin{array}{l}\text { I would like to receive training on the assessment and } \\
\text { treatment of IPV }(n=146)\end{array}$} \\
\hline Yes & 71 & $49 \%$ \\
\hline No & 39 & $27 \%$ \\
\hline Unsure & 31 & $21 \%$ \\
\hline Not applicable to my practice & 5 & $3 \%$ \\
\hline
\end{tabular}

IPV = intimate partner violence.

years were more likely to agree with the statement "In many cases, the battering would stop if the batterer would quit abusing alcohol" than those 40 years or younger or 41 to 50 years ( $\mathrm{p}=0.04, \chi^{2}$ with Yates correction).

Most respondents (82\%) indicated that $26 \%$ to $50 \%$ of their practices involved treating female patients, and $80 \%$ of respondents indicated that greater than $25 \%$ of their female patients were treated after sustaining injuries (causes included falls from heights, motor vehicle crashes, work injuries, and IPV-related incidents). Most surgeons (74\%), however, responded that female victims of IPV represented $5 \%$ or less of all injured female patients treated per year.

Barriers to screening for IPV included time constraints (14\%) (Table 1), lack of knowledge regarding what to ask (29\%), and lack of knowledge regarding what to do if a patient responds that she is a victim of IPV (33\%) (Table 3). Some surgeons were uncomfortable with asking about IPV owing to concerns about invasion of patient privacy $(5 \%)$, personal and patient safety $(26 \%$ and $18 \%$, respectively), and offending the patient (21\%) (Table 1). Most respondents indicated that identifying victims of IPV was relevant to their practices $(74 \%)$, and $51 \%$ of respondents disagreed that assessing female patients for IPV is a low-priority issue (Table 3). Seventy-seven of 145 respondents $(53 \%)$ reported being unsure if reporting IPV was mandatory in their jurisdictions (Table 3). Only $23 \%$ of respondents had attended an educational or training session regarding IPV. Few respondents' clinics (8\%) had written guidelines for IPV detection and treatment. Most respondents (72\%) agreed that provisions of information of signs and indicators of IPV to orthopaedic surgeons could be beneficial to stopping the abuse in some cases. Nevertheless, only $49 \%$ of respondents said they would like to receive training on the assessment and treatment of IPV as it relates to the orthopaedic profession.

\section{Discussion}

Domestic violence is the most common cause of nonfatal injury to women, many of which are musculoskeletal injuries and therefore relevant to orthopaedic surgeons. However, there is a paucity of data regarding how surgeons perceive, identify, and ultimately treat victims of IPV in the orthopaedic clinical setting. This study aimed to identify (1) surgeon attitudes and beliefs regarding batterers and victims of IPV and (2) surgeon perceptions regarding the identification and role in assisting victims of IPV in their orthopaedic practices.

Our study had multiple limitations that must be considered. First, the low response rate $(22 \%)$ may indicate a nonresponder bias. Although our response rate is similar to other surveys of IPV among healthcare providers (range, $14 \%-83 \%)[8,13,16,19,23,26,28]$, the data should be interpreted with caution. Second, our results may not be generalizable to practices across the world, as the survey was administered to North American orthopaedic traumatologists only. Third, the survey specifically targeted orthopaedic surgeons with greater than $50 \%$ of their practices, research, and/or educational programming related directly to orthopaedic traumatology - a requirement for OTA membership. This survey, therefore, likely misses a substantial number of orthopaedic surgeons in general practice (and perhaps, not members of the OTA) who may be first-line providers of care to victims of IPV. Fourth, our study specifically focuses on surgeons' perceptions of violence perpetrated by men on their female intimate partners; no inferences can be made regarding their perceptions of the prevalence of IPV by women on men or in same-sex relationships.

The main purpose of our study was to determine surgeons' attitudes and beliefs regarding victims of IPV and batterers. Approximately $20 \%$ or more respondents revealed multiple misconceptions, such as victims must be getting something out of the abusive relationships, some women have personalities that cause the abuse, and the battering would stop if the batterer quit abusing alcohol. This shows a strong need for implementation of standard 
practice guidelines and continuing education concerning IPV screening and management in orthopaedics.

The second aim of our study was to determine how orthopaedic surgeons identify and treat potential victims of IPV. Respondents indicated that identifying victims was relevant to their orthopaedic practices although they believed that the prevalence of IPV among their patients was rare. This is likely a gross misperception. A recent study examining the prevalence of IPV in orthopaedic fracture clinics found a 12-month prevalence rate of $17.8 \%$ across North American centers [4]. Respondents also were uncomfortable with identifying and treating victims of IPV and believed that multiple barriers existed for effective identification and assistance of victims. Barriers included lack of knowledge regarding what to ask, what to do if patients report a positive history of IPV, and the community resources available. They also reported a lack of time available for such an inquiry. Targeted educational programs may help to alleviate some or all of these barriers. It is likely that training in this area will help providers recognize signs and symptoms of IPV, direct their inquiries appropriately and efficiently, and allow them to provide appropriate advice and treatment to victims. Physician training in the recognition and management of female patients with IPV was associated with greater preparedness on the part of providers for screening and assistance of such patients $[17,24]$. Only approximately $1 / 2$ of responding surgeons knew whether reporting IPV was mandatory in their jurisdictions. Less than one in 10 respondents had clinics with written guidelines for detection or management of IPV. The importance of recognizing and dealing with IPV is noted by some states but is not countrywide. Reporting of domestic violence, in most circumstances, is required only in California, Colorado, Florida, Georgia, Kentucky (children only), Michigan, and Ohio [2]. Some states do indicate that reporting is required if the injury results as a consequence of a "criminal act". Alaska, Florida, and Kentucky are the only states that mandate training for healthcare professionals regarding domestic violence, although may states have created (optional) programs for training healthcare professionals [2].

Our survey suggests members of the OTA believe that IPV is relevant to their practices, but hold multiple misconceptions regarding victims and batterers, and perceive multiple barriers to screening and treating these patients. Future research on IPV in orthopaedic patients may include studies of prevalence among patients in orthopaedic fracture clinics and studies evaluating the effectiveness of different screening and intervention methods. This research would be beneficial for informational purposes and in providing a rationale for encouraging education in IPV recognition, counseling, and management among orthopaedic surgeons who routinely treat female patients with musculoskeletal injuries. Targeted educational programs to orthopaedic surgeons involved in the routine care of patients with musculoskeletal injuries might be beneficial to improve the care delivered to female victims of IPV.

Acknowledgments We thank Nicole Simunovic MSc, for assistance with manuscript formatting and editing, and David A. Volgas $\mathrm{MD}$, for assistance with statistical analysis.

\section{References}

1. American Academy of Orthopaedic Surgeons. Advisory statement - Domestic and family violence and abuse: the orthopaedic surgeon's responsibilities. Document 1030. Available at: http:// www.aaos.org/about/papers/advistmt/1030.asp. Accessed October $18,2012$.

2. American Academy of Orthopaedic Surgeons. Family violence state statutes. Available at: http://www.aaos.org/about/abuse/sts tatut.asp. Accessed October 18, 2012.

3. Bhandari M, Dosanjh S, Tornetta P 3rd, Matthews D; Violence AgainsWwomen health Research Collaborative. Musculoskeletal manifestations of physical abuse after intimate partner violence. J Trauma. 2006;61:1473-1479.

4. Bhandari M, Sprague S, Dosanjh S, Petrisor B, Resendes S, Madden K, Schemitsch EH; P.R.A.I.S.E. Investigators. The prevalence of intimate partner violence across orthopaedic fracture clinics in Ontario. J Bone Joint Surg Am. 2011;93:132-141.

5. Bhandari M, Sprague S, Tornetta P 3rd, D'Aurora V, Schemitsch E, Shearer H, Brink O, Mathews D, Dosanjh S; Violence Against Women Health Research Collaborative. (Mis)perceptions about intimate partner violence in women presenting for orthopaedic care: a survey of Canadian orthopaedic surgeons. J Bone Joint Surg Am. 2008;90:1590-1597.

6. Borkowski M, Murch M, Walker V. Marital Violence: The Community Response. London, UK: Tavistock; 1983;115-125.

7. Canadian Orthopaedic Association. Intimate partner violence: position statement. 2009. Available at: http://www.coa-aco.org/ library/health-policy/intimate-partner-violence.html. Accessed October 18, 2012.

8. Chambliss LR, Bay RC, Jones RF 3rd. Domestic violence: an educational imperative? Am J Obstet Gynecol. 1995;172: 1035-1038.

9. Dannenberg AL, Baker SP, Li G. Intentional and unintentional injuries in women: an overview. Ann Epidemiol. 1994;4:133-139.

10. Dobash RE, Dobash R. Violence Against Wives: A Case Against the Patriarchy. New York, NY: Free Press; 1979:179-206.

11. Easteal PW, Easteal S. Attitudes and practices of doctors toward spouse assault victims: an Australian study. Violence Vict. 1992; 7:217-228.

12. Fishman PA, Bonomi AE, Anderson ML, Reid RJ, Rivara FP. Changes in health care costs over time following the cessation of intimate partner violence. J Gen Intern Med. 2010; 25:920-925.

13. Gutmanis I, Beynon C, Tutty L, Wathen CN, MacMillan HL. Factors influencing identification of and response to intimate partner violence: a survey of physicians and nurses. BMC Public Health. 2007;7:12.

14. Kyriacou DN, Anglin D, Taliaferro E, Stone S, Tubb T, Linden JA, Muelleman R, Barton E, Kraus JF. Risk factors for injury to women from domestic violence against women. $N$ Engl J Med. 1999;341:1892-1898.

15. Maiuro RD, Vitaliano PP, Sugg NK, Thompson DC, Rivara FP, Thompson RS. Development of a health care provider survey for 
domestic violence: psychometric properties. Am J Prev Med. 2000;19:245-252.

16. McCloskey LA, Lichter E, Ganz ML, Williams CM, Gerber MR, Sege R, Stair T, Herbert B. Intimate partner violence and patient screening across medical specialties. Acad Emerg Med. 2005;12:712-722.

17. Narayan AP, Socolar RR, St Claire K. Pediatric residency training in child abuse and neglect in the United States. Pediatrics. 2006;117:2215-2221.

18. National Center for Injury Prevention and Control. Costs of Intimate Partner Violence Against Women in the United States. Atlanta, GA: Centers for Disease Control and Prevention; 2003.

19. Parsons LH, Zaccaro D, Wells B, Stovall TG. Methods of and attitudes toward screening obstetrics and gynecology patients for domestic violence. Am J Obstet Gynecol. 1995;173:381-386; discussion 386-387.

20. Plichta SB, Falik M. Prevalence of violence and its implications for women's health. Womens Heath Issues. 2001;11:244-258.

21. Prosman GJ, Lo Fo Wong SH, Bulte E, Lagro-Janssen AL. Healthcare utilization by abused women: a case control study. Eur J Gen Pract 2012;18:107-113.

22. Reid SA, Glasser M. Primary care physicians' recognition of and attitudes toward domestic violence. Acad Med. 1997;72:51-53.
23. Rodriguez MA, Bauer HM, McLouglin E, Grumbach K. Screening and intervention for intimate partner abuse: practices and attitudes of primary care physicians. JAMA. 1999;282:468-474.

24. Roelens K, Verstraelen H, Van Egmond K, Temmerman M. A knowledge, attitudes, and practice survey among obstetriciangynaecologists on intimate partner violence in Flanders, Belgium. BMC Public Health. 2006;6:238.

25. Rose K, Saunders DG. Nurses' and physicians' attitudes about women abuse: the effects of gender and professional role. Health Care Women Int. 1986;7:427-438.

26. Shearer HM, Forte ML, Dosanjh S, Mathews DJ, Bhandari M. Chiropractors' perceptions about intimate partner violence: a cross-sectional survey. J Manipulative Physiol Ther. 2006;29: 386-392.

27. US Department of Justice, Federal Bureau of Investigation. Crime in the United States: uniform crime reports. 1997. Available at: http://www.fbi.gov/about-us/cjis/ucr/crime-in-the-u.s/1997/ toc97.pdf. Accessed October 18, 2012.

28. Waalen J, Goodwin MM, Spitz AM, Petersen R, Saltzman LE. Screening for intimate partner violence by health care providers: barriers and interventions. Am J Prev Med. 2000;19: 230-237. 